\title{
Mucormycosis in Burn Patients
}

\author{
Pauline Devauchelle ${ }^{1}$, Mathieu Jeanne ${ }^{1,2}$ and Emilie Fréalle ${ }^{3,4, *}$ \\ 1 CHU Lille, Centre des Brûlés, F-59000 Lille, France; pauline.clementgrandcourt@chru-lille.fr (P.D.); \\ mathieu.jeanne@chru-lille.fr (M.J.) \\ 2 Univ. Lille, Inserm, CHU Lille, CIC 1403-Centre d'Investigation Clinique, F-59000 Lille, France \\ 3 CHU Lille, Laboratoire de Parasitologie-Mycologie, F-59000 Lille, France \\ 4 Univ. Lille, CNRS, Inserm, CHU Lille, Institut Pasteur de Lille, U1019-UMR8204-CIIL-Center for Infection \\ and Immunity of Lille, F-59000 Lille, France \\ * Correspondence: emilie.frealle@chru-lille.fr; Fax: +33-3-20-44-48-95
}

Received: 7 February 2019; Accepted: 20 March 2019; Published: 21 March 2019

check for updates

\begin{abstract}
Patients with extensive burns are an important group at risk for cutaneous mucormycosis. This study aimed to perform a systematic review of all reported mucormycosis cases in burn patients from 1990 onward. A Medline search yielded identification of 7 case series, 3 outbreaks, and 25 individual cases reports. The prevalence reached $0.04 \%-0.6 \%$. The median age was $42-48$ in the case series and outbreaks, except for the studies from military centers (23.5-32.5) and in individual reports (29.5). The median total body surface area reached $42.5 \%-65 \%$. Various skin lesions were described, none being pathognomonic: the diagnosis was mainly reached because of extensive necrotic lesions sometimes associated with sepsis. Most patients were treated with systemic amphotericin B or liposomal amphotericin B, and all underwent debridement and/or amputation. Mortality reached $33 \%-100 \%$ in the case series, $29 \%-62 \%$ during outbreaks, and $40 \%$ in individual cases. Most patients were diagnosed using histopathology and/or culture. Mucorales qPCR showed detection of circulating DNA 2-24 days before the standard diagnosis. Species included the main clinically relevant mucorales (i.e., Mucor, Rhizopus, Absidia/Lichtheimia, Rhizomucor) but also more uncommon mucorales such as Saksenaea or Apophysomyces. Contact with soil was reported in most individual cases. Bandages were identified as the source of contamination in two nosocomial outbreaks.
\end{abstract}

Keywords: mucormycosis; burn; cutaneous; qPCR; outbreak; molecular typing; environmental source; nosocomial; Saksenaea; Apophysomyces

\section{Introduction}

Patients with extensive burns are an important group at risk for cutaneous mucormycosis. The first two cases were reported in 1961 by Rabin et al. [1]. Several reviews on cutaneous mucormycosis have been published, showing mostly localized infection or accompanied with deep extension, but few have shown dissemination [2]. Clinical presentation is characterized by rapid progression to necrosis and a better prognosis than other clinical forms of mucormycosis ( $31 \%$ mortality). Although these reviews include burn patients, none is specifically focused on them. In 2005, Roden et al. identified 11 cases of cutaneous mucormycosis in burns among 176 patients (6\%) before 2004 [2]. Then, Ledgard et al. reviewed all published cutaneous mucormycosis cases from 1966 to 2006 and found that burns were amongst the most commonly reported factors, representing 19 out of 145 cases (13\%) [3]. Lastly, in 2009, Skiada and Petrikkos analyzed seven case reports published from 2004 and 2008 [4], and, in 2012, Skiada et al., identified two supplementary cases in 2009-2010 [5].

Since no review focusing on burn patients has been published so far, this study aimed to perform a systematic review of all reported mucormycosis cases in burn patients. We undertook a Medline 
search using the keywords "mucormycosis" or "Lichtheimia" or "Absidia" or "Mucor" or "Rhizopus" or "Rhizomucor" and "burn". Non-English language papers were excluded. We included individual case reports (including those which had been analyzed in previous reviews on cutaneous mucormycosis), case series reports (i.e., including at least two patients), and outbreak reports published from 1990 onward, in order to collect data on the prevalence of mucormycosis in burn patients; clinical, diagnosis, and therapeutic features; the species involved; and the results of environmental investigations in individual cases and outbreaks. Recent data on molecular diagnosis (real-time PCR) were also included.

\section{Results of PubMed Search}

A Medline search yielded seven case series from the USA $(n=3)$, Australia $(n=1)$, France $(n=1)$, Greece $(n=1)$, and across Europe $(n=1)$ [6-12]. Three nosocomial outbreaks were reported: one in Belgium in 2005 and two in France in 2018 [13-16]. Lastly, 25 reports of individual cases were identified between 1990 and 2019, including publications from the USA $(n=12$, with three cases occurring in the Middle East (Afghanistan, Iraq) and one in Japan) [17-28], from Asia ( $n=6$; two in China, three in India, one in Iran) [29-34], from Europe ( $n=3$; in Czech Republic, Germany, and the U.K.) [35-37], from Australia $(n=3)[3,38,39]$, and from Ecuador $(n=1)$ [40]. The data from case series and outbreaks are summarized in Table 1. The epidemiological, clinical, diagnosis, and therapeutic features of burn patients with mucormycosis from individual case reports are presented in Table 2.

\section{Prevalence of Mucormycosis in Burn Patients}

The prevalence of mucormycosis was reported from three cases series between 1991 and 2009 in the Brooke Army Medical Center (USA), ranging from $0.1 \%$ to $0.6 \%$ [6-8]. Similar prevalences of $0.5 \%$ and $0.6 \%$ have been more recently reported in France and in Greece, in studies covering the 2000-2011 and 2005-2014 periods, respectively [9,10]. Katz et al. reported a lower prevalence of $0.04 \%$ in a study conducted between 2001 and 2011 in Australia [11]. Increased prevalences of mucormycosis were observed during two outbreaks in Belgium (18.5\%) [13] and in France (10.7\%) [16]. Two case series and one outbreak report have differentiated colonization by mucorales, which, according to the system developed at the United States Army Institute of Surgical Research Burn Center, is defined by fungal presence without penetration into viable tissue (superficial colonization, microorganisms in non-viable tissue or microorganisms at the interface of viable tissue), and infection, which corresponds to an invasion of fungi into viable tissue below the eschar of a specimen (microinvasion of viable tissue, deep or generalized invasion of viable tissue, or microvascular invasion) [41]. In these three studies, colonized patients represented $29 \%$ to $41 \%$ of patients with positive culture $[8,10,13]$.

\section{Epidemiological, Clinical, and Therapeutic Features of Mucormycosis in Burn Patients}

In case series and outbreaks, the median age ranged from 42 to 48 , except for in studies from military centers in the USA or in France, which reported lower median ages of 23.5 and 32.5, respectively (Table 1). When analyzing data from the 25 individual cases retrieved using Medline, we found a median age of 29.5 (10-63), which was lower than that in case series and outbreaks (Table 2). Cases mostly occurred in men in the case series (6 men vs. no women) and individual reports (18 men vs. 6 women), but the number of men and women who developed mucormycosis was similar during outbreaks (Table 1). The median percentage of the total body surface area (TBSA) affected by a burn reached $42.5 \%$ to $65 \%$ in case series and outbreaks (Table 1$)$ and $58 \%(4 \%-96 \%)$ when analyzing individual case reports (Table 2). Most of the patients with lower TBSA $(<40 \%)$ presented with diabetes mellitus, which was the most common underlying condition (20\%). Hyperglycemia poorly controllable by high-dose insulin was reported prior to the diagnosis of mucormycosis in two patients with diabetes [17,29]. It was associated with metabolic acidosis in one patient [17]. Few patients had other underlying conditions, such as ethanol or drug abuse or cardiovascular diseases. The most common clinical forms of mucormycosis were cutaneous, but three patients presented rhinocerebral, cerebral, or retro-orbitary infection (12\%) (Table 2). Pulmonary localization was reported in one 
patient during an outbreak [14], and chronic osteomyelitis of the lower limb was associated with sinus infection 5 months after a burn in one patient [33]. One study reported septic shock and uncontrollable disseminated intravascular coagulation causing fatal cerebrovascular stroke [35]. From a clinical point of view, an invasive mucormycosis infection cannot be related to any specific cutaneous lesion. The literature describes various skin lesions, none being pathognomonic [12]: in most case reports, the diagnosis is reached because of extensive necrotic lesions sometimes associated with sepsis, in most cases after a first excision procedure $[3,11,19,20,29,30,32,35,37]$. In the other case reports, cutaneous lesions are not described, and the diagnosis is made based on an early skin biopsy $[12,23,26]$.

Most patients were treated with systemic amphotericin B or liposomal amphotericin B, and all underwent debridement and/or amputation (Table 2). Local treatment with amphotericin B was used in three patients. Although posaconazole and isavuconazole can also be considered for the treatment of mucormycosis [42,43], only three reports of treatment with posaconazole and/or isavuconazole were identified in three patients, including two patients who underwent initial treatment with liposomal amphotericin B [14,33]. In the third patient, posaconazole was followed by isavuconazole and associated with local amphotericin B [27]. Surprisingly, one patient with low TBSA $(4 \%-5 \%)$ who presented diabetes mellitus with hyperglycemia and was poorly controllable by high-dose insulin was successfully treated with voriconazole, which is known to lack meaningful in vitro activity against Mucorales [29]. Mortality ranged from 33\% to $100 \%$ in the case series and from $29 \%$ to $62 \%$ during outbreaks. The overall mortality in the individual cases was $40 \%$, with a $100 \%$ mortality rate in the three patients diagnosed with rhinocerebral, cerebral, or retro-orbitary infection (Table 2).

\section{Mycological Diagnosis}

\subsection{Standard Diagnosis}

Diagnosis of mucormycosis in burn patients generally relies on the histopathological analysis and culture of skin biopsies. However, since fungal colonization may represent $29 \%$ to $41 \%$ of patients with detection of mucorales in culture (Table 1), isolation alone may not be helpful to differentiate colonization and infection. When analyzing the individual reports in Table 2, most patients were found to have been diagnosed using histopathology $(61 \%)$ and/or culture $(87 \%)$. No antifungal susceptibility testing was performed. The median delay between burn and diagnosis was 13 days (3-150 days), and in 14 out of 21 patients (67\%), mucormycosis manifested within the initial 2 weeks after admission. This short delay was consistent with the inoculation of the patient's burn wounds with the fungi during the burn injury, whereas the 36 day median delay between admission and diagnosis (18-95 days) reported in one outbreak was more indicative of a nosocomial contamination [14].

\subsection{Molecular Diagnosis}

Several real-time PCR methods have been developed to detect and identify Mucorales in tissue samples. Most of them target clinically relevant mucormycetes of the Mucorales order, including Mucor, Rhizopus, Rhizomucor, and Absidia/Lichtheimia species [44,45]. Interestingly, a real-time PCR targeting Lichtheimia, Rhizopus/Mucor, and Rhizomucor for detection of mucorales DNA in serum developed by Millon et al. [46,47] was retrospectively and prospectively evaluated in 75 burn patients during an outbreak in Saint-Louis hospital. This study showed detection of circulating mucorales DNA 2 to 24 days before the standard diagnosis (direct examination or culture) in 10 patients with mucormycosis (including 2 patients from two other centers) and a decline of circulating mucorales DNA in patients under treatment [16]. Furthermore, a persistent positive qPCR after treatment initiation was shown to be associated with death.

\subsection{Species Involved}

Mucorales species identified in infected or colonized patients from the case series included mainly Mucor spp. $(n=11)$ (Table 1). Rhizopus spp., Absidia/Lichtheimia spp., and Rhizomucor spp. were 
identified in four, two, and two patients, respectively. Rare species such as Saksenaea vasiformis or Saksenaea erythrospora were isolated in two patients that were injured in Iraq or Afghanistan. Two out of the three reported outbreaks were due to Absidia/Lichtheimia spp. In the third one, M. circinelloides was the main species (in six out of eight cases). In individual case reports, mucorales species were isolated by culture in 16 patients. Saksenaea species were the most frequent species $(n=4$; in Iraq, Afghanistan, Australia, and Ecuador), followed by Absidia/Lichtheimia spp. ( $n=6$; in Afghanistan, U.K., USA, Czech Republic, and India $(n=2))$, Mucor spp. $(n=3$ : in the USA), Rhizopus spp. $(n=3$; in the USA, China, Germany), and Apophysomyces spp. ( $n=2$; in Australia, Japan). Rhizomucor pusillus was identified in one patient (Australia), and Cunninghamella elegans in another patient (Afghanistan). For three patients, the mucorales species was not identified.

Morphological identification was confirmed by molecular methods only in four patients with Saksenaea spp. or Apophysomyces variabilis infection, including one patient who had coinfection with $S$. vasiformis, C. elegans, and Lichtheimia corymbifera (Table 2). Identification was also confirmed in two out of three outbreaks, yielding M. circinelloides or L. corymbifera [16] and L. ramosa or L. ornata [14], but no molecular identification was reported in the case series.

Mixed infections due to two distinct mucorales or one mucorale and another filamentous fungus are reported in a few studies. For example, a combined infection by Absidia/Lichtheimia sp., Aspergillus fumigatus, and Fusarium sp. was reported by Lipovy et al. [36]. Schaal et al. also found two mucormycosis cases with co-infection with Aspergillus [10], and Atty et al. and Schofield et al. found other co-infections with Fusarium sp. [6,19]. Lastly, a co-infection with several mucorales species was reported by Farmer et al. (S. vasiformis, C. elegans, and L. corymbifera associated with Aspergillus, Geotrichum, Alternaria) and by Fréalle et al. (L. ornata and Rhizopus delemar) [14].

Bacterial co-infections or antibiotic treatments, which put burn patients at particular risk of invasive fungal infection, were mentioned in 14 individual case reports. The higher mortality in these patients $(57 \%)$ than in patients with no bacterial infection or antibiotic treatment $(18 \%)$ was consistent with increased disease severity if there are confirmed or suspected bacterial co-infections (Table 2).

\section{Environmental Investigations of Mucormycosis in Individual Cases and Outbreaks}

When analyzing the circumstances of burns in individual reports, contact with soil after the burn injury was reported in four cases, with the patient rolling in soil or muddy ground water to extinguish the flames, and was consistent with an inoculation with the fungi at the time of the burn injury (Table 2). Burn causes included traffic accident $(n=4)$, airplane crash $(n=2)$, improvised explosive device blast $(n=3)$ or workplace explosion $(n=1)$, gasoline fire $(n=3)$, domestic accident (with tap water or during cooking; $n=3)$, and high-voltage electric contact $(n=1)$. The absence of exposure to an infectious environment was specified in one report [35]. In the case series, combat-related burns $[8,10]$ or forest blaze [9] were reported. Altogether, these etiologies included common locations/settings in which the burns occur, such as cooking, tap water, or electric contact [48], but common etiologies for flames in the household, such as barbecues or the use of gasoline, were not reported. Conversely, trauma circumstances were over-represented.

Environmental investigations were performed in the three outbreaks of mucormycosis that were reported in burn units [13-16]. During the first outbreak, which was due to L. corymbifera and reported in 2005 in Belgium [13], air, surface, or water samples and non-sterile Elastoplast bandages were analyzed by culture. These analyses yielded detection of L. corymbifera in bandages, confirming that Elastoplast bandages were the source of contamination of patients. However, no molecular confirmation was performed. Bandages were also identified as the potential source of contamination in seven serial cases of Lichtheimia mucormycosis in the burn unit of the University Hospital of Lille between 2013 and 2016 [14]. Analysis by culture of non-sterile crepe and Elastoplast bandages showed only one crepe bandage positive for Lichtheimia sp., but the genotypic relatedness of the strains between patients and bandage strains could not be confirmed since further multi-locus sequence typing (MLST) of this environmental strain and of the seven Lichtheimia clinical strains revealed different species 
in patients (L. ramosa and L. ornata), and in the bandage (L. corymbifera). However, Lichtheimia spp. and Lichtheimia species-specific qPCR revealed the presence of L. ramosa and/or L. ornata in most crepe and elasticized bandages, which were frequently contaminated by different Lichtheimia strains. A third outbreak of mucormycosis due to M. circinelloides $f$. circinelloides was reported in the burn units of the Saint-Louis Hospital, Paris, France, and another in hospital in a Paris suburb (Hôpital d'Instruction des Armées, Clamart, France) during the same period; these occurred between 2013 and 2015 and involved six and four patients, respectively $[15,16]$. MLST and whole-genome sequencing analysis of the patient's isolates revealed a large diversity of isolates in the different patients, with most strains being patient-specific and within the same patient, with two patients being infected by a mixture of strains. These data were consistent with the presence of a local environmental "reservoir" containing clonally unrelated isolates (probably linens or Elastoplast). However, this reservoir could not be identified since all the environmental samples that were analyzed by culture were negative, and, although Mucor/Rhizopus qPCR was also used, it was positive only in the Bair Hugger filters that were used during the hospitalization of three patients.

\section{Conclusions}

Mucormycosis is a rare disease in burn patients but remains difficult to treat and is often lethal. The clinical and prognostic features are similar to those in other patients with cutaneous mucormycosis (such as trauma or surgery). The treatment is also similar, relying on early diagnosis; extensive surgical debridement (including amputation when appropriate), which is rendered necessary for the complete resection of necrotized and infected tissue; and intravenous administration of high doses of amphotericin B or liposomal amphotericin B [4]. Glucose control and correction of acidosis are also required in patients with diabetes mellitus. qPCR detection of mucorales DNA in serum represents a promising tool to improve outcomes for patients by enabling early diagnosis. It could also be useful to differentiate colonization versus infection. The species responsible for mucormycosis in burn patients include the main clinically relevant mucorales (i.e., Mucor Rhizopus, Absidia/Lichtheimia, Rhizomucor) but also uncommon mucorales such as Saksenaea or Apophysomyces. Nevertheless, data on molecular identification would be needed to attain reliable epidemiological data. Since inoculation of soil-dwelling moulds into wounds can occur at the time of injury, the context in which burns occur needs to be taken into account in order to evaluate the risk of mucormycosis. In nosocomial outbreaks, bandages appeared to be the main source of contamination with various mucorales strains, underlying the need to use sterile bandages on burn patients. 
Table 1. Case series or outbreaks of mucormycosis in burn patients.

\begin{tabular}{|c|c|c|c|c|c|c|c|c|c|c|c|}
\hline & Country & Type of Unit & Period of Study & $\begin{array}{l}\text { Number of } \\
\text { Patients } \\
\text { Admitted }\end{array}$ & $\begin{array}{l}\text { Number of } \\
\text { Cases }\end{array}$ & $\begin{array}{l}\text { Median } \\
\text { Age; } \\
\text { Gender }\end{array}$ & $\begin{array}{l}\text { Median } \\
\text { TBSA (\%) }\end{array}$ & Mucorales Species & $\begin{array}{l}\text { Prevalence of } \\
\text { Patients with } \\
\text { Mucormycosis }\end{array}$ & Mortality & Refs \\
\hline \multirow{7}{*}{ Case Series } & \multirow{3}{*}{$\begin{array}{l}\text { USA } \\
\text { (Texas) }\end{array}$} & \multirow{3}{*}{$\begin{array}{l}\text { Military adult } \\
\text { burn center }\end{array}$} & 1991-2002 & 2651 & $\begin{array}{l}16 \text { cases, } 11 \\
\text { colonized } \\
\text { patients }\end{array}$ & NA & NA & NA & $\begin{array}{l}0.6 \% \text { (cases), } 1.0 \% \\
\quad \text { (including } \\
\text { colonization) }\end{array}$ & NA & [7] \\
\hline & & & $\begin{array}{l}\text { Apr 2000-March } \\
2005\end{array}$ & 2036 & 2 & NA & NA & Mucor sp. (2) & $0.1 \%$ & $100 \%$ & [6] \\
\hline & & & Jan 2003-Nov 2009 & 2449 & $\begin{array}{l}12(7 \text { with } \\
\text { positive } \\
\text { culture) }\end{array}$ & $23.5 ; \mathrm{NA}$ & 60 & $\begin{array}{c}\text { Mucor circinelloides (2), } \\
\text { Saksenaea vasiformis (1), } \\
\text { Saksenaea erythrospora (1), } \\
\text { Pythium aphanidermatum * } \\
\text { (1) }\end{array}$ & $0.5 \%$ & $54 \%$ & [8] \\
\hline & $\begin{array}{l}\text { Australia } \\
\text { (Melbourne) }\end{array}$ & $\begin{array}{l}\text { Adult Burns } \\
\text { Service }\end{array}$ & Jan 2001-June 2011 & NA & 3 & $42 ; 3 \mathrm{M} / 0 \mathrm{~F}$ & 65 & $\begin{array}{l}\text { Mucor sp. (1), Mucor } \\
\text { ramosissimus (1), Absidia } \\
\text { corymbifera (1) }\end{array}$ & $0.04 \%$ & $33 \%$ & [11] \\
\hline & $\begin{array}{l}\text { France } \\
\text { (Paris) }\end{array}$ & $\begin{array}{l}\text { Military adult } \\
\text { burn center }\end{array}$ & 2000-2011 & 1849 & $\begin{array}{c}6 \text { cases, } 3 \\
\text { colonized } \\
\text { patients }\end{array}$ & $32.5 ; \mathrm{NA}$ & 42.5 & $\begin{array}{l}\text { Mucor sp. (2), Mucor } \\
\text { circinelloides (2), Mucor } \\
\text { racemosus (1), Lichtheimia } \\
\text { ornata (1), Rhizopus oryzae } \\
\text { (1), Rhizomucor variabilis } \\
\text { (1), Rhizopus stolonifer (1) }\end{array}$ & $\begin{array}{l}0.3 \% \text { (cases), } 0.5 \% \\
\text { (including } \\
\text { colonization) }\end{array}$ & $33 \%$ & [10] \\
\hline & Europe & $\mathrm{NA}$ & $2005-2007$ & NA & 7 & NA & $\mathrm{NA}$ & $\mathrm{NA}$ & NA & $33 \%$ & [12] \\
\hline & $\begin{array}{l}\text { Greece } \\
\text { (Athens) }\end{array}$ & $\begin{array}{l}\text { Adult Burns } \\
\text { Service }\end{array}$ & 2005-2014 & 477 & 3 & $47 ; 3 \mathrm{M} / 0 \mathrm{~F}$ & 50 & $\begin{array}{l}\text { Rhizomucor (2), Rhizopus } \\
\text { (1) }\end{array}$ & $0.6 \%$ & $67 \%$ & [9] \\
\hline & $\begin{array}{l}\text { Belgium } \\
\text { (Liège) }\end{array}$ & $\begin{array}{l}\text { Plastic Surgery } \\
\text { and burns unit }\end{array}$ & May-Sept 2004 & 27 & $\begin{array}{c}5 \text { cases, } 2 \\
\text { colonized } \\
\text { patients }\end{array}$ & NA & NA & Absidia corymbifera (7) & $\begin{array}{l}18.5 \% \text { (cases) } \\
25.9 \% \text { (including } \\
\text { colonization) }\end{array}$ & $60 \%$ & [13] \\
\hline Outbreaks & $\begin{array}{l}\text { France } \\
\text { (Paris) }\end{array}$ & $\begin{array}{l}\text { Burn intensive } \\
\text { care unit }\end{array}$ & Oct 2013-Feb 2016 & 75 & 8 & $48 ; 4 \mathrm{M} / 4 \mathrm{~F}$ & 62 & $\begin{array}{c}\text { Mucor circinelloides (6), } \\
\text { Mucor or Rhizopus (1), } \\
\text { Lichtheimia corymbifera (1) }\end{array}$ & $10.7 \%$ & $62 \%$ & {$[15,16]$} \\
\hline & $\begin{array}{c}\text { France } \\
\text { (Lille) }\end{array}$ & Burn unit & $\begin{array}{l}\text { Nov 2013-July } \\
2016\end{array}$ & $\mathrm{NA}$ & 7 & $43 ; 4 \mathrm{M} / 3 \mathrm{~F}$ & 50 & $\begin{array}{c}\text { Lichtheimia ramosa }(5), \\
\text { Lichtheimia ornata }(1), \\
\text { Lichtheimia ornata/Rhizopus } \\
\text { delemar }(1)\end{array}$ & NA & $29 \%$ & [14] \\
\hline
\end{tabular}

$\mathrm{NA}=$ Not available; $\mathrm{M}=$ Male, $\mathrm{F}=$ Female; ${ }^{*}$ Pythium aphanidermatum, which belongs to the Oomycota, was erroneously included in the mucormycosis cases in the study by Mitchell et al. Median age, total body surface area (TBSA), prevalence, and mortality are given for the 11 mucormycosis cases and the P. aphanidermatum case; ${ }^{£}$ Rhizomucor variabilis var. variabilis is currently known as Mucor irregularis. 
Table 2. Epidemiological, clinical, diagnosis, and therapeutic features of burn patients with mucormycosis from individual cases or case series reports.

\begin{tabular}{|c|c|c|c|c|c|c|c|c|c|c|}
\hline $\begin{array}{l}\text { Country, Year } \\
\text { of Publication, } \\
\text { and Reference }\end{array}$ & Age/Sex & Circumstances of Burn & TBSA & $\begin{array}{l}\text { Underlying } \\
\text { Condition * }\end{array}$ & Localization & Clinical Presentation & $\begin{array}{l}\text { Date of Diagnosis } \\
\text { and Method } \\
\text { (H = Histology, } \\
\text { M = Microscopy, } \\
\text { C = Culture) }\end{array}$ & $\begin{array}{c}\text { Species and Date } \\
\text { of Isolation } \\
(* *=\text { Molecular } \\
\text { Confirmation of } \\
\text { Identification })\end{array}$ & $\begin{array}{l}\text { Antifungal (Date of } \\
\text { Beginning) and Other } \\
\text { Treatments }\end{array}$ & Outcome \\
\hline $\begin{array}{c}\text { Australia } \\
\text { (Darwin) } 1990 \\
\text { [38] }\end{array}$ & $45 / \mathrm{M}$ & $\begin{array}{l}\text { Covered with moist soil } \\
\text { during his attempts to } \\
\text { extinguish the flames }\end{array}$ & 25 & No & Right ankle & $\begin{array}{l}\text { Fever, subcutaneous } \\
\text { swelling }\end{array}$ & D32 $(\mathrm{M}, \mathrm{C})$ & $\begin{array}{c}\text { Apophysomyces } \\
\text { elegans }\end{array}$ & $\begin{array}{l}\text { AmB IV (D33) } \\
\text { Debridement } \\
\text { Amputation }\end{array}$ & Improved \\
\hline $\begin{array}{c}\text { USA } \\
\text { (Washington) } \\
1993 \text { [24] }\end{array}$ & $42 / \mathrm{F}$ & $\begin{array}{l}\text { Doused in alcohol and } \\
\text { ignited. Rolling in mud } \\
\text { to extinguish the flames }\end{array}$ & 67 & $\begin{array}{c}\text { Ethanol } \\
\text { abuse } \\
\text { Bact } \mathcal{E} A B T\end{array}$ & $\begin{array}{c}\text { Upper } \\
\text { extremities }\end{array}$ & $\begin{array}{l}\text { Edema of forearm, } \\
\text { necrosis of muscles of } \\
\text { flexor compartment, } \\
\text { secondary necrosis of } \\
\text { left hand }\end{array}$ & $\begin{array}{c}\text { D12 (C) \& D16 } \\
(\mathrm{H}, \mathrm{C})\end{array}$ & Mucor & $\begin{array}{c}\text { AmB IV (D17) } \\
\text { Debridement } \\
\text { Amputation right arm } \\
\text { and left hand }\end{array}$ & $\begin{array}{l}\text { Deceased } \\
\text { D22 }\end{array}$ \\
\hline $\begin{array}{l}\text { USA (Durham) } \\
1997 \text { [25] }\end{array}$ & $28 / \mathrm{F}$ & Tap water & NA & $\begin{array}{l}\text { Diabetes } \\
\text { mellitus }\end{array}$ & $\begin{array}{l}\text { Right hand } \\
\text { and forearm }\end{array}$ & $\begin{array}{l}\text { Life-threatening } \\
\text { necrosis of hand and } \\
\text { forearm }\end{array}$ & NA $(H, C)$ & Rhizopus oryzae & Arm amputation & Improved \\
\hline $\begin{array}{l}\text { China (Dalian) } \\
\text { 1998 [32] }\end{array}$ & $40 / \mathrm{F}$ & Liquid gas explosion & 85 & No & $\begin{array}{l}\text { Trunk and } \\
\text { limbs }\end{array}$ & $\begin{array}{c}\text { Fever, tachycardia, } \\
\text { extensive edema, } \\
\text { multifocal indurated } \\
\text { nodules rapidly } \\
\text { extensive }\end{array}$ & D6 $(\mathrm{H}, \mathrm{C})$ & $\begin{array}{l}\text { Rhizopus } \\
\text { rhizopodiformis }\end{array}$ & $\begin{array}{c}\text { AmB IV, oral 5-FC (D7) } \\
\text { AmB local (D10) } \\
\text { Debridement, }\end{array}$ & Improved \\
\hline $\begin{array}{l}\text { USA (Ohio) } \\
1999 \text { [17] }\end{array}$ & $62 / \mathrm{M}$ & Airplane crash & 29 & $\begin{array}{l}\text { Diabetes } \\
\text { mellitus, } \\
\text { hypertension, } \\
\text { coronary } \\
\text { disease } \\
\end{array}$ & Rhinocerebral & $\begin{array}{l}\text { Depression of the right } \\
\text { supraorbital rim, } \\
\text { multiple organ failure }\end{array}$ & $\mathrm{D} 4(\mathrm{H})$ & NA & Debridement & $\begin{array}{l}\text { Deceased } \\
\text { D11 }\end{array}$ \\
\hline $\begin{array}{c}\text { Ecuador } \\
\text { (Guayaquil) } \\
2006 \text { [40] }\end{array}$ & $13 / \mathrm{M}$ & $\begin{array}{c}\text { Domestic accident. } \\
\text { Patient rolled on the } \\
\text { ground to extinguish } \\
\text { the flames then applied } \\
\text { oil to prevent water or } \\
\text { plasma loss. }\end{array}$ & 65 & $\begin{array}{c}\text { No } \\
\text { Bact } \mathcal{E} A B T\end{array}$ & NA & $\begin{array}{l}\text { Lysis of an area of the } \\
\text { graft in the sacrum } \\
\text { region with fetid and } \\
\text { purulent exudate }\end{array}$ & D7 $(\mathrm{M}, \mathrm{C})$ & Saksenaea vasiformis & $\begin{array}{l}\text { AmB IV (D8) } \\
\text { Debridement }\end{array}$ & Improved \\
\hline $\begin{array}{l}\text { Australia } \\
\text { (Adelaide) } \\
2008[3]\end{array}$ & $35 / \mathrm{M}$ & $\begin{array}{l}\text { Motor vehicle accident } \\
\text { with car burning. } \\
\text { Rolling in dirt to } \\
\text { extinguish the flames. }\end{array}$ & 60 & $\begin{array}{c}\text { No } \\
\text { Bact } \& A B T\end{array}$ & Arms, legs & $\begin{array}{l}\text { Severe aggressive and } \\
\text { rapid necrosis of right } \\
\text { lower leg, new necrotic } \\
\text { areas in previously } \\
\text { debrided zones }\end{array}$ & D5 \& D17 (C) & Saskena vasiformis ** & $\begin{array}{l}\text { L-AmB IV (D19) } \\
\text { Debridement } \\
\text { Below knee and above } \\
\text { elbow amputation }\end{array}$ & Improved \\
\hline $\begin{array}{c}\text { U.K. } \\
\text { (Birmingham) } \\
2008 \text { [37] }\end{array}$ & $27 / \mathrm{M}$ & $\begin{array}{c}\text { Road traffic accident in } \\
\text { Kenya }\end{array}$ & 45 & $\begin{array}{c}\text { No } \\
\text { Bact } \mathcal{E} A B T\end{array}$ & $\begin{array}{l}\text { Trunk, arms, } \\
\text { legs, face }\end{array}$ & $\begin{array}{l}\text { Circular black area in } \\
\text { the burned zone }\end{array}$ & D21 $(\mathrm{H}, \mathrm{C})$ & Absidia corymbifera & $\begin{array}{l}\text { L-AmB IV (D21) Local } \\
\text { nystatin (D25) } \\
\text { Debridement }\end{array}$ & Improved \\
\hline
\end{tabular}


Table 2. Cont

\begin{tabular}{|c|c|c|c|c|c|c|c|c|c|c|}
\hline $\begin{array}{l}\text { Country, Year } \\
\text { of Publication, } \\
\text { and Reference }\end{array}$ & Age/Sex & Circumstances of Burn & TBSA & $\begin{array}{l}\text { Underlying } \\
\text { Condition * }\end{array}$ & Localization & Clinical Presentation & $\begin{array}{l}\text { Date of Diagnosis } \\
\text { and Method } \\
\text { (H = Histology, } \\
M=\text { Microscopy, } \\
\text { C = Culture) }\end{array}$ & $\begin{array}{l}\text { Species and Date } \\
\text { of Isolation } \\
(* *=\text { Molecular } \\
\text { Confirmation of } \\
\text { Identification })\end{array}$ & $\begin{array}{l}\text { Antifungal (Date of } \\
\text { Beginning) and Other } \\
\text { Treatments }\end{array}$ & Outcome \\
\hline $\begin{array}{l}\text { USA (Michigan) } \\
2009 \text { [23] }\end{array}$ & $25 / \mathrm{F}$ & $\begin{array}{l}\text { Car accident with } \\
\text { burning caused by } \\
\text { gasoline }\end{array}$ & 45 & Obesity & Face & $\begin{array}{l}\text { Fever, no specific lesion. } \\
\text { Early biopsy }\end{array}$ & D9 (C) & Mucor sp. & $\begin{array}{l}\text { L-AmB IV and local } \\
\text { (D9) } \\
\text { Debridement }\end{array}$ & Improved \\
\hline $\begin{array}{l}\text { USA (Texas) } \\
2009[26]\end{array}$ & $10 / \mathrm{M}$ & Warehouse fire & 96 & No & Jaw & NA & NA & NA & $\begin{array}{l}\text { Mandibular } \\
\text { debridement }\end{array}$ & Improved \\
\hline $\begin{array}{c}\text { Czech Republic } \\
\text { (Brno) } \\
2009[36]\end{array}$ & NA & NA & 82 & $\begin{array}{l}\text { NA } \\
\text { Bact }\end{array}$ & NA & NA & NA & $\begin{array}{c}\text { Absidia sp., } \\
\text { Aspergillus } \\
\text { fumigatus, Fusarium } \\
\text { sp. } \\
\end{array}$ & NA & Deceased \\
\hline $\begin{array}{l}\text { Germany (Halle) } \\
2010 \text { [35] }\end{array}$ & $29 / \mathrm{M}$ & $\begin{array}{l}\text { Clothes ignition during } \\
\text { welding. No exposure } \\
\text { to infectious } \\
\text { environment. }\end{array}$ & 54 & $\begin{array}{l}\text { No } \\
A B T\end{array}$ & $\begin{array}{l}\text { Chest, neck, } \\
\text { axilla, left } \\
\text { shoulder, } \\
\text { back }\end{array}$ & $\begin{array}{l}\text { New deep muscular } \\
\text { tissues necrosis under } \\
\text { the skin grafts, systemic } \\
\text { signs of sepsis }\end{array}$ & D13 (C) & Rhizopus oryzae & $\begin{array}{l}\text { AmB IV (D13) } \\
\text { Debridement }\end{array}$ & $\begin{array}{l}\text { Deceased } \\
\text { D15 }\end{array}$ \\
\hline $\begin{array}{l}\text { Australia (Perth) } \\
2010 \text { [39] }\end{array}$ & $34 / \mathrm{M}$ & $\begin{array}{l}\text { Plane crash. Flames } \\
\text { extinguished by muddy } \\
\text { ground water }\end{array}$ & 60 & $\begin{array}{c}\text { No } \\
\text { Bact } \mathcal{E} A B T\end{array}$ & $\begin{array}{l}\text { Legs, left } \\
\text { upper limb, } \\
\text { back, } \\
\text { abdomen }\end{array}$ & $\begin{array}{c}\text { Necrosis, } \\
\text { vesiculo-bullous rash, } \\
\text { progressive } \\
\text { myconecrosis }\end{array}$ & $\mathrm{NA}(\mathrm{H}, \mathrm{C})$ & $\underset{£}{\text { Rhizomucor variabilis }}$ & $\begin{array}{l}\text { L-AmB IV Debridement } \\
\text { Left above-knee and } \\
\text { right below-knee } \\
\text { amputations }\end{array}$ & Improved \\
\hline $\begin{array}{l}\text { USA (Texas) } \\
2011[18]\end{array}$ & $26 / \mathrm{M}$ & $\begin{array}{l}\text { Improvised explosive } \\
\text { device blast in Iraq }\end{array}$ & 56 & $\begin{array}{l}\text { No } \\
\text { Bact }\end{array}$ & $\begin{array}{l}\text { Head and } \\
\text { neck, } \\
\text { retro-orbitary }\end{array}$ & Proptosis of left eye & $\mathrm{D} 14(\mathrm{H}, \mathrm{C})$ & $\begin{array}{l}\text { Saksenaea } \\
\text { erythrospora ** }\end{array}$ & $\begin{array}{l}\text { Enucleation of the left } \\
\text { eye }\end{array}$ & $\begin{array}{l}\text { Deceased } \\
\text { D100 }\end{array}$ \\
\hline $\begin{array}{c}\text { China (Beijing) } \\
2012 \text { [31] }\end{array}$ & $24 / \mathrm{M}$ & NA & 80 & $\begin{array}{c}\text { No } \\
\text { Bact } \mathcal{E} A B T\end{array}$ & Thigh, chest & $\begin{array}{l}\text { Dark necrotic muscle } \\
\text { on right thigh and chest }\end{array}$ & $\mathrm{D} 24(\mathrm{H}, \mathrm{C})$ & Mucorale & $\begin{array}{l}\text { L-AmB IV (D26) } \\
\text { Debridements }\end{array}$ & $\begin{array}{c}\text { Deceased } \\
\text { D33 }\end{array}$ \\
\hline $\begin{array}{l}\text { USA (Chicago) } \\
2014 \text { [19] }\end{array}$ & $20 / \mathrm{M}$ & $\begin{array}{l}\text { Doused in gasoline and } \\
\text { set on fire }\end{array}$ & 92 & No & $\begin{array}{l}\text { Left upper } \\
\text { extremity }\end{array}$ & $\begin{array}{l}\text { Development of } \\
\text { nonviable muscle tissue } \\
\text { that demonstrated } \\
\text { black plaques and } \\
\text { white nodules }\end{array}$ & D13 $(\mathrm{H}, \mathrm{C})$ & $\begin{array}{l}\text { Mucorale } \\
\text { Fusarium sp. }\end{array}$ & $\begin{array}{l}\text { AmB IVand local; } \\
\text { L-AmB (D13) } \\
\text { Debridement } \\
\text { Left upper extremity } \\
\text { amputation }\end{array}$ & $\begin{array}{l}\text { Deceased } \\
\text { D31 }\end{array}$ \\
\hline $\begin{array}{c}\text { India } \\
\text { (New Delhi) } \\
2014 \text { [30] }\end{array}$ & $20 / \mathrm{F}$ & $\begin{array}{l}\text { Accidental flame burns } \\
\text { while cooking }\end{array}$ & 60 & $\begin{array}{c}\text { No } \\
\text { Bact } \mathcal{E} A B T\end{array}$ & Thighs & $\begin{array}{l}\text { Liquefaction and } \\
\text { necrosis on initial deep } \\
\text { dermal burns }\end{array}$ & $\mathrm{D} 14(\mathrm{H}, \mathrm{C})$ & L. ramosa & $\begin{array}{l}\text { AmB IV (D14) } \\
\text { Debridement }\end{array}$ & Improved \\
\hline $\begin{array}{l}\text { USA (Texas) } \\
2014 \text { [22] }\end{array}$ & $21 / \mathrm{M}$ & $\begin{array}{c}\text { U.S. } \\
\text { Marine-self-immolation } \\
\text { with gasoline while } \\
\text { stationed in Okinawa, } \\
\text { Japan }\end{array}$ & 90 & No & Back & NA & D8 $(\mathrm{H}, \mathrm{C})$ & $\begin{array}{l}\text { Apophysomyces } \\
\text { variabilis ** }\end{array}$ & $\begin{array}{l}\text { L-AmB IV (D8) } \\
\text { Debridement }\end{array}$ & Deceased \\
\hline
\end{tabular}


Table 2. Cont.

\begin{tabular}{|c|c|c|c|c|c|c|c|c|c|c|}
\hline $\begin{array}{l}\text { Country, Year } \\
\text { of Publication, } \\
\text { and Reference }\end{array}$ & Age/Sex & Circumstances of Burn & TBSA & $\begin{array}{l}\text { Underlying } \\
\text { Condition * }\end{array}$ & Localization & Clinical Presentation & $\begin{array}{c}\text { Date of Diagnosis } \\
\text { and Method } \\
(\mathrm{H}=\text { Histology, } \\
\text { M = Microscopy, } \\
\text { C = Culture })\end{array}$ & $\begin{array}{c}\text { Species and Date } \\
\text { of Isolation } \\
(* *=\text { Molecular } \\
\text { Confirmation of } \\
\text { Identification })\end{array}$ & $\begin{array}{c}\text { Antifungal (Date of } \\
\text { Beginning) and Other } \\
\text { Treatments }\end{array}$ & Outcome \\
\hline $\begin{array}{c}\text { USA } \\
2015[21]\end{array}$ & $30 / \mathrm{M}$ & $\begin{array}{l}\text { Improvised explosive } \\
\text { device blast in } \\
\text { Afghanistan }\end{array}$ & 20 & No & $\begin{array}{c}\text { Lower } \\
\text { extremities }\end{array}$ & NA & D3 $(\mathrm{H}, \mathrm{C})$ & $\begin{array}{c}\text { Saksenaea } \\
\text { erythrospora, A. } \\
\text { flavus, A. terreus, } \\
\text { Fusarium } \\
\end{array}$ & $\begin{array}{l}\text { L-AmB IV (D15) } \\
\text { Debridement } \\
\text { Lower extremities } \\
\text { amputation }\end{array}$ & Improved \\
\hline $\begin{array}{l}\text { USA (Texas) } \\
2015 \text { [28] }\end{array}$ & $22 / \mathrm{M}$ & $\begin{array}{l}\text { Improvised explosive } \\
\text { device blast in } \\
\text { Afghanistan }\end{array}$ & 19 & $\begin{array}{c}\text { No } \\
\text { Bact } \& A B T\end{array}$ & $\begin{array}{c}\text { Upper and } \\
\text { lower } \\
\text { extremities, } \\
\text { left } \\
\text { abdomen, } \\
\text { brain }\end{array}$ & $\begin{array}{l}\text { Plant material and } \\
\text { necrotic tissue within } \\
\text { wounds }\end{array}$ & D17 (C) & $\begin{array}{l}\text { Saksenaea vasiformis } \\
* * \text {, Cunninghamella } \\
\text { elegans **, } \\
\text { Lichtheimia } \\
\text { corymbifera **, } \\
\text { Aspergillus, } \\
\text { Geotrichum, } \\
\text { Alternaria }\end{array}$ & $\begin{array}{c}\text { L-AmB IV (D12) and } \\
\text { local AmB } \\
\text { DebridementRight } \\
\text { above-knee amputation } \\
\text { and hip disarticulation }\end{array}$ & $\begin{array}{l}\text { Deceased } \\
\text { D44 }\end{array}$ \\
\hline $\begin{array}{l}\text { Iran (Shiraz) } \\
2017 \text { [29] }\end{array}$ & $50 / \mathrm{F}$ & NA & $4-5$ & $\begin{array}{l}\text { Diabetes } \\
\text { mellitus }\end{array}$ & $\begin{array}{l}\text { Right arm, } \\
\text { chest, breast }\end{array}$ & $\begin{array}{l}\text { Deep and extensive } \\
\text { necrosis of muscles, } \\
\text { systemic signs of sepsis }\end{array}$ & D17 (H) & NA & $\begin{array}{l}\text { Voriconazole IV (D17) } \\
\text { Debridement }\end{array}$ & Improved \\
\hline $\begin{array}{l}\text { USA (New York) } \\
\quad 2017 \text { [20] }\end{array}$ & $56 / \mathrm{M}$ & $\begin{array}{l}\text { Rollover motor vehicle } \\
\text { accident (struck a tree) }\end{array}$ & 20 & $\begin{array}{c}\text { Diabetes } \\
\text { mellitus, } \\
\text { hypothyroidism, } \\
\text { hepatitis } C, \\
\text { intravenous } \\
\text { drug abuse } \\
\text { Bact } \mathcal{E} A B T\end{array}$ & $\begin{array}{c}\text { Lower } \\
\text { extremities }\end{array}$ & $\begin{array}{l}\text { Sloughing of the grafts, } \\
\text { necrotic skin and } \\
\text { muscle, systemic signs } \\
\text { of sepsis }\end{array}$ & $\mathrm{D} 43(\mathrm{H}, \mathrm{C})$ & Mucor sp. & $\begin{array}{c}\text { Debridement } \\
\text { Below-knee and } \\
\text { above-knee amputation }\end{array}$ & $\begin{array}{l}\text { Deceased } \\
\text { D44 }\end{array}$ \\
\hline $\begin{array}{l}\text { India (New } \\
\text { Delhi) } \\
2018 \text { [33] }\end{array}$ & $40 / \mathrm{M}$ & NA & NA & No & $\begin{array}{l}\text { Lower limb } \\
\text { (osteomyelitis) } \\
\text { and sinus }\end{array}$ & $\begin{array}{l}\text { Black eschar with pale } \\
\text { granulation; Pain, fever, } \\
\text { chills }\end{array}$ & $\mathrm{D} 150(\mathrm{H})$ & NA & $\begin{array}{c}\text { L-AmB IV, } \\
\text { posaconazole VO } \\
\text { Debridement Sinus } \\
\text { tract excision; above } \\
\text { knee amputation }\end{array}$ & Improved \\
\hline $\begin{array}{c}\text { India } \\
\text { (Heydarabad) } \\
\text { 2018 [34] }\end{array}$ & $32 / \mathrm{M}$ & $\begin{array}{l}\text { High-voltage electrical } \\
\text { contact }\end{array}$ & NA & No & Scalp & $\begin{array}{l}\text { Hyphae over wound } \\
\text { margin and gangrenous } \\
\text { changes over scalp } \\
\text { surrounding the wound }\end{array}$ & D12 (C) & Absidia corymbifera & $\begin{array}{c}\text { AmB IV } \\
\text { Debridement }\end{array}$ & Improved \\
\hline $\begin{array}{c}\text { USA } \\
\text { (Minnesota) } \\
2019[27]\end{array}$ & $63 / \mathrm{M}$ & Workplace explosion & 47 & $\begin{array}{c}\text { Diabetes } \\
\text { mellitus, } \\
\text { myocardial } \\
\text { infarction } \\
\text { Bact } \& A B T\end{array}$ & $\begin{array}{c}\text { Upper } \\
\text { extremities } \\
\text { chest, } \\
\text { abdomen, } \\
\text { and flanks }\end{array}$ & $\begin{array}{l}\text { Multiple small white } \\
\text { plaque }\end{array}$ & $\mathrm{D} 10(\mathrm{C})$ & Lichtheimia sp. & $\begin{array}{c}\text { Posaconazole IV (D10), } \\
\text { isavuconazole IV (D22), } \\
\text { AmB local } \\
\text { Debridement }\end{array}$ & Improved \\
\hline
\end{tabular}

* Presence of bacterial co-infection and antibiotic treatment are indicated by "Bact" or "ABT", respectively; ${ }^{£}$ Rhizomucor variabilis var. variabilis is currently known as Mucor irregularis; NA

$=$ Not available; $\mathrm{AmB}=$ Amphotericin B, L-AmB = Liposomal Amphotericin B. 
Author Contributions: Writing, P.D. and E.F.; review and editing, M.J.

Funding: No funding was received.

Conflicts of Interest: The authors declare no conflict of interest.

\section{References}

1. Rabin, E.R.; Lundberg, G.D.; Mitchell, E.T. Mucormycosis in severely burned patients. Report of two cases with extensive destruction of the face and nasal cavity. N. Engl. J. Med. 1961, 264, 1286-1289. [CrossRef] [PubMed]

2. Roden, M.M.; Zaoutis, T.E.; Buchanan, W.L.; Knudsen, T.A.; Sarkisova, T.A.; Schaufele, R.L.; Sein, M.; Sein, T.; Chiou, C.C.; Chu, J.H.; et al. Epidemiology and outcome of zygomycosis: A review of 929 reported cases. Clin. Infect. Dis. 2005, 41, 634-653. [CrossRef] [PubMed]

3. Ledgard, J.P.; van Hal, S.; Greenwood, J.E. Primary cutaneous zygomycosis in a burns patient: A review. J. Burn Care Res. 2008, 29, 286-290. [CrossRef] [PubMed]

4. Skiada, A.; Petrikkos, G. Cutaneous zygomycosis. Clin. Microbiol. Infect. 2009, 15, 41-45. [CrossRef] [PubMed]

5. Skiada, A.; Rigopoulos, D.; Larios, G.; Petrikkos, G.; Katsambas, A. Global epidemiology of cutaneous zygomycosis. Clin. Dermatol. 2012, 30, 628-632. [CrossRef] [PubMed]

6. Schofield, C.M.; Murray, C.K.; Horvath, E.E.; Cancio, L.C.; Kim, S.H.; Wolf, S.E.; Hospenthal, D.R. Correlation of culture with histopathology in fungal burn wound colonization and infection. Burns 2007, 33, 341-346. [CrossRef] [PubMed]

7. Horvath, E.E.; Murray, C.K.; Vaughan, G.M.; Chung, K.K.; Hospenthal, D.R.; Wade, C.E.; Holcomb, J.B.; Wolf, S.E.; Mason, A.D.; Cancio, L.C. Fungal wound infection (not colonization) is independently associated with mortality in burn patients. Ann. Surg. 2007, 245, 978-985. [CrossRef]

8. Mitchell, T.A.; Hardin, M.O.; Murray, C.K.; Ritchie, J.D.; Cancio, L.C.; Renz, E.M.; White, C.E. Mucormycosis attributed mortality: A seven-year review of surgical and medical management. Burns 2014, 40, 1689-1695. [CrossRef]

9. Kyriopoulos, E.J.; Kyriakopoulos, A.; Karonidis, A.; Gravvanis, A.; Gamatsi, I.; Tsironis, C.; Tsoutsos, D. Burn injuries and soft tissue traumas complicated by mucormycosis infection: A report of six cases and review of the literature. Ann. Burns Fire Disasters 2015, 28, 280-287.

10. Schaal, J.V.; Leclerc, T.; Soler, C.; Donat, N.; Cirrode, A.; Jault, P.; Bargues, L. Epidemiology of filamentous fungal infections in burned patients: A French retrospective study. Burns 2015, 41, 853-863. [CrossRef]

11. Katz, T.; Wasiak, J.; Cleland, H.; Padiglione, A. Incidence of non-candidal fungal infections in severe burn injury: An Australian perspective. Burns 2014, 40, 881-886. [CrossRef] [PubMed]

12. Skiada, A.; Pagano, L.; Groll, A.; Zimmerli, S.; Dupont, B.; Lagrou, K.; Lass-Florl, C.; Bouza, E.; Klimko, N.; Gaustad, P.; et al. Zygomycosis in Europe: Analysis of 230 cases accrued by the registry of the European Confederation of Medical Mycology (ECMM) Working Group on Zygomycosis between 2005 and 2007. Clin. Microbiol. Infect. 2011, 17, 1859-1867. [CrossRef] [PubMed]

13. Christiaens, G.; Hayette, M.P.; Jacquemin, D.; Melin, P.; Mutsers, J.; De Mol, P. An outbreak of Absidia corymbifera infection associated with bandage contamination in a burns unit. J. Hosp. Infect. 2005, 61, 88. [CrossRef] [PubMed]

14. Fréalle, E.; Rocchi, S.; Bacus, M.; Bachelet, H.; Pasquesoone, L.; Tavernier, B.; Mathieu, D.; Millon, L.; Jeanne, M. Real-time polymerase chain reaction detection of Lichtheimia species in bandages associated with cutaneous mucormycosis in burn patients. J. Hosp. Infect. 2018, 99, 68-74. [CrossRef] [PubMed]

15. Garcia-Hermoso, D.; Criscuolo, A.; Lee, S.C.; Legrand, M.; Chaouat, M.; Denis, B.; Lafaurie, M.; Rouveau, M.; Soler, C.; Schaal, J.V.; et al. Outbreak of Invasive Wound Mucormycosis in a Burn Unit Due to Multiple Strains of Mucor circinelloides f. circinelloides Resolved by Whole-Genome Sequencing. MBio 2018, 9, e00573-18. [CrossRef] [PubMed]

16. Legrand, M.; Gits-Muselli, M.; Boutin, L.; Garcia-Hermoso, D.; Maurel, V.; Soussi, S.; Benyamina, M.; Ferry, A.; Chaussard, M.; Hamane, S.; et al. Detection of circulating Mucorales DNA in critically ill burn patients: Preliminary report of a screening strategy for early diagnosis and treatment. Clin. Infect. Dis. 2016, 63, 1312-1317. [CrossRef] 
17. Stern, L.E.; Kagan, R.J. Rhinocerebral mucormycosis in patients with burns: Case report and review of the literature. J. Burn Care Rehabil. 1999, 20, 303-306. [CrossRef] [PubMed]

18. Hospenthal, D.R.; Chung, K.K.; Lairet, K.; Thompson, E.H.; Guarro, J.; Renz, E.M.; Sutton, D.A. Saksenaea erythrospora infection following combat trauma. J. Clin. Microbiol. 2011, 49, 3707-3709. [CrossRef]

19. Atty, C.; Alagiozian-Angelova, V.M.; Kowal-Vern, A. Black plaques and white nodules in a burn patient. Fusarium and Mucormycosis. JAMA Dermatol. 2014, 150, 1355-1356. [CrossRef]

20. Stanistreet, B.; Bell, D. Burn Wound Mucormycosis: A Case Study on Poor Wound Healing. J. Burn Care Res. 2017, 38, e582-e584. [CrossRef]

21. Akers, K.S.; Rowan, M.P.; Niece, K.L.; Graybill, J.C.; Mende, K.; Chung, K.K.; Murray, C.K. Antifungal wound penetration of amphotericin and voriconazole in combat-related injuries: Case report. BMC Infect. Dis. 2015, 15, 184. [CrossRef] [PubMed]

22. Dela Cruz, W.P.; Calvano, T.P.; Griffith, M.E.; White, C.E.; Kim, S.H.; Sutton, D.A.; Thompson, E.H.; Fu, J.; Wickes, B.L.; Guarro, J.; et al. Invasive Apophysomyces variabilis infection in a burn patient. J. Clin. Microbiol. 2012, 50, 2814-2817. [CrossRef] [PubMed]

23. Piazza, R.C.; Thomas, W.L.; Stawski, W.S.; Ford, R.D. Mucormycosis of the face. J. Burn Care Res. 2009, 30, 520-523. [CrossRef]

24. Kraut, E.J.; Jordan, M.H.; Steiner, C.R. Arterial occlusion and progressive gangrene caused by mucormycosis in a patient with burns. J. Burn Care Rehabil. 1993, 14, 552-556. [CrossRef] [PubMed]

25. Lidor, C.; Nunley, J.A. Images in clinical medicine. Mucormycosis of the hand and forearm. N. Engl. J. Med. 1997, 337, 1511. [CrossRef] [PubMed]

26. Antonetti, J.; Killyon, G.W.; Chang, P.; McCauley, R.L. Microvascular transfer of burned tissue for mandibular reconstruction. J. Burn Care Res. 2009, 30, 536-539. [CrossRef]

27. Thielen, B.K.; Barnes, A.M.T.; Sabin, A.P.; Huebner, B.; Nelson, S.; Wesenberg, E.; Hansen, G.T. Widespread Lichtheimia Infection in a Patient with Extensive Burns: Opportunities for Novel Antifungal Agents. Mycopathologia 2019, 184, 121-128. [CrossRef]

28. Farmer, A.R.; Murray, C.K.; Driscoll, I.R.; Wickes, B.L.; Wiederhold, N.; Sutton, D.A.; Sanders, C.; Mende, K.; Enniss, B.; Feig, J.; et al. Combat-Related Pythium aphanidermatum Invasive Wound Infection: Case Report and Discussion of Utility of Molecular Diagnostics. J. Clin. Microbiol. 2015, 53, 1968-1975. [CrossRef]

29. Ayaz, M.; Moein, R. Myocutaneous Mucormycosis in a Diabetic Burnt Patient Led to Upper Extremity Amputation; A Case Report. Bull. Emerg. Trauma 2017, 5, 58-62.

30. Kaur, R.; Bala, K.; Ahuja, R.B.; Srivastav, P.; Bansal, U. Primary cutaneous mucormycosis in a patient with burn wounds due to Lichtheimia ramosa. Mycopathologia 2014, 178, 291-295. [CrossRef]

31. Li, F.; Yang, H.; Chai, J.; Wang, H. Burn wound mucormycosis: A case report. J. Burn Care Res. 2012, 33, e24-e25. [CrossRef]

32. Tang, D.; Wang, W. Successful cure of an extensive burn injury complicated with Mucor wound sepsis. Burns 1998, 24, 72-73. [CrossRef]

33. Bhatt, M.; Soneja, M.; Fazal, F.; Vyas, S.; Kumar, P.; Jorwal, P.; Raj, U.; Sachdev, J.; Singh, G.; Xess, I.; et al. Two cases of osteoarticular Mucor menace: A diagnostic and management conundrum. Drug Discov. Ther. 2018, 12, 374-378. [CrossRef]

34. Moon, P.; Jithendran, N. Invasive Fungal Infection with Absidia corymbifera in Immunocompetent Patient with Electrical Scalp Burn. World J. Plast. Surg. 2018, 7, 249-252.

35. Struck, M.F.; Illert, T.; Stiller, D.; Steen, M. Basilar artery occlusion after multifactor coagulopathy including Rhizopus oryzae infection in burns. J. Burn Care Res. 2010, 31, 955-958. [CrossRef]

36. Lipový, B.; Rihová, H.; Hanslianová, M.; Kocmanová, I.; Zaloudíková, Z.; Kaloudová, Y.; Suchánek, I.; Mager, R.; Krupicová, H.; Slezák, M.; et al. Unsuccessful therapy of combined mycotic infection in a severely burned patient: A case study. Acta Chir. Plast. 2009, 51, 83-84.

37. Constantinides, J.; Misra, A.; Nassab, R.; Wilson, Y. Absidia corymbifera fungal infection in burns: A case report and review of the literature. J. Burn Care Res. 2008, 29, 416-419. [CrossRef]

38. Cooter, R.D.; Lim, I.S.; Ellis, D.H.; Leitch, I.O. Burn wound zygomycosis caused by Apophysomyces elegans. J. Clin. Microbiol. 1990, 28, 2151-2153.

39. Ribeiro, N.F.F.; Heath, C.H.; Kierath, J.; Rea, S.; Duncan-Smith, M.; Wood, F.M. Burn wounds infected by contaminated water: Case reports, review of the literature and recommendations for treatment. Burns 2010, 36, 9-22. [CrossRef] 
40. Vega, W.; Orellana, M.; Zaror, L.; Gené, J.; Guarro, J. Saksenaea vasiformis infections: Case report and literature review. Mycopathologia 2006, 162, 289-294. [CrossRef]

41. Howard, P.; Cancio, L.C.; McManus, A.; Goodwin, C.; Kim, S.; Pruitt, B. What's new in burn-associated infections? Curr. Surg. 1999, 397-405. [CrossRef]

42. Marty, F.M.; Ostrosky-Zeichner, L.; Cornely, O.A.; Mullane, K.M.; Perfect, J.R.; Thompson, G.R.; Alangaden, G.J.; Brown, J.M.; Fredricks, D.N.; Heinz, W.J.; et al. Isavuconazole treatment for mucormycosis: A single-arm open-label trial and case-control analysis. Lancet Infect. Dis. 2016, 16, 828-837. [CrossRef]

43. Cornely, O.A.; Arikan-Akdagli, S.; Dannaoui, E.; Groll, A.H.; Lagrou, K.; Chakrabarti, A.; Lanternier, F.; Pagano, L.; Skiada, A.; Akova, M.; et al. ESCMID and ECMM joint clinical guidelines for the diagnosis and management of mucormycosis 2013. Clin. Microbiol. Infect. 2014, 20, 5-26. [CrossRef] [PubMed]

44. Bernal-Martínez, L.; Buitrago, M.J.; Castelli, M.V.; Rodriguez-Tudela, J.L.; Cuenca-Estrella, M. Development of a single tube multiplex real-time PCR to detect the most clinically relevant Mucormycetes species. Clin. Microbiol. Infect. 2013, 19, E1-E7. [CrossRef] [PubMed]

45. Hrncirova, K.; Lengerova, M.; Kocmanova, I.; Racil, Z.; Volfova, P.; Palousova, D.; Moulis, M.; Weinbergerova, B.; Winterova, J.; Toskova, M.; et al. Rapid detection and identification of mucormycetes from culture and tissue samples by use of high-resolution melt analysis. J. Clin. Microbiol. 2010, 48, 3392-3394. [CrossRef]

46. Millon, L.; Larosa, F.; Lepiller, Q.; Legrand, F.; Rocchi, S.; Daguindau, E.; Scherer, E.; Bellanger, A.-P.; Leroy, J.; Grenouillet, F. Quantitative polymerase chain reaction detection of circulating DNA in serum for early diagnosis of mucormycosis in immunocompromised patients. Clin. Infect. Dis. 2013, 56, e95-e101. [CrossRef] [PubMed]

47. Millon, L.; Herbrecht, R.; Grenouillet, F.; Morio, F.; Alanio, A.; Letscher-Bru, V.; Cassaing, S.; Chouaki, T.; Kauffmann-Lacroix, C.; Poirier, P.; et al. Early diagnosis and monitoring of mucormycosis by detection of circulating DNA in serum: Retrospective analysis of 44 cases collected through the French Surveillance Network of Invasive Fungal Infections (RESSIF). Clin. Microbiol. Infect. 2016, 22, e1-e810. [CrossRef]

48. Müller, M.; Moser, E.M.; Pfortmueller, C.A.; Olariu, R.; Lehmann, B.; Exadaktylos, A.K. Aetiology of adult burns treated from 2000 to 2012 in a Swiss University Hospital. Burns 2016, 42, 919-925. [CrossRef] 